\title{
Hydrolyzed collagen intake increases bone mass of growing rats trained with running exercise
}

\author{
Satoko Takeda ${ }^{1}$, Jong-Hoon Park ${ }^{2,3}$, Eriko Kawashima ${ }^{4}$, Ikuko Ezawa ${ }^{5}$ and Naomi Omi ${ }^{1,6,7^{*}}$
}

\begin{abstract}
Background: Some studies have shown that dietary hydrolyzed collagen peptides (HC) effectively prevent age-related bone loss. However, it is not known whether the intake of $\mathrm{HC}$ also has positive effect on bone mass or strength when combined with exercise during growth phase.

Methods: We examined the effects of 11 weeks of $\mathrm{HC}$ intake and running exercise on bone mass and strength in growing rats. Rats were randomized into four groups, the 20\% casein group (Casein20), the $40 \%$ casein group (Casein40), the 20\% HC group (HC20), and the 40\% HC group (HC40). Each group was further divided into exercise groups (Casein20 + Ex, Casein40 + Ex, HC20 + Ex, HC40 + Ex) and non-exercise group (Casein20, Casein40, HC20, HC40). In the HC intake groups, 30\% of casein protein was replaced with HC. Exercise group rats were trained 6 days per week on a treadmill (25-30 m/min, $60 \mathrm{~min})$ for 60 days. After being sacrificed, their bone mineral content (BMC) and bone strength were evaluated.
\end{abstract}

Results: Exercise and dietary HC effects were observed in the adjusted BMC of lumbar spine and tibia among the 20\% protein groups ( $p<0.001$ for exercise; $p<0.05$ for dietary $H C$, respectively). These effects were also noted in the adjusted wet weight and dry weight of femur among the 20\% protein groups $(p<0.001, p<0.01$ for exercise; $p<0.01, p<0.001$ for dietary $\mathrm{HC}$, respectively). On the other hand, in adjusted bone breaking force and energy, dietary HC effect was not significant. Among the $40 \%$ protein groups, similar results were obtained in the adjusted BMC, femoral weight, bone breaking force, and energy. There were no differences between the 20\% protein groups and the $40 \%$ protein groups.

Conclusions: The present study demonstrated that moderate HC intake (where the diet contains 20\% protein, of which $30 \%$ is $\mathrm{HC}$ ) increased bone mass during growth period and further promoted the effect of running exercise. On the other hand, a higher $\mathrm{HC}$ intake (where the diet contains $40 \%$ protein, of which $30 \%$ is HC) had no more beneficial effect on bone mass than the moderate $\mathrm{HC}$ intake.

Keywords: Hydrolyzed collagen peptides, Bone mass, Bone strength, Physical exercise, Growing phase, Rats

\section{Background}

It is generally well accepted that physiologically mechanical loading, e.g., physical activity or exercise, plays important roles in having higher bone mass during growth period [1]. In addition, nutritional factors such as protein are essential for increasing bone formation [2]. Thus, for achieving peak bone mass during growing phase, not only mechanical loading but also sustaining adequate protein intake may be of significance. In particular, although young athletes involved in physical training have high protein intakes [3],

\footnotetext{
* Correspondence: ominaomi@taiiku.tsukuba.ac.jp

${ }^{1}$ Graduate School of Comprehensive Human Sciences, University of Tsukuba, Ibaraki, Japan

${ }^{6}$ Faculty of Health and Sport Sciences, University of Tsukuba, Ibaraki, Japan Full list of author information is available at the end of the article
}

the effects of protein intake and physical exercise on growing bone have not been well understood.

Type I collagen is the major structural protein, being the main extra cellular matrix protein for calcification. It is distributed throughout the whole body accounting for $25 \%$ of total body protein and for $80 \%$ of total conjunctive tissue in humans [4]. The synthesis of type I collagen also plays a role in further promoting osteoblast differentiation $[5,6]$. Collagen peptides, the enzymatic degradation products of collagens, have recently been shown to have several biological activities, and have been used as preservatives [7-9]. The intake of hydrolyzed collagen peptides (HC) in animal models has been shown to improve bone mineral density (BMD) and bone mineral content (BMC) [10], and

\section{Biomed Central}

(c) 2013 Takeda et al.; licensee BioMed Central Ltd. This is an Open Access article distributed under the terms of the Creative Commons Attribution License (http://creativecommons.org/licenses/by/2.0), which permits unrestricted use, distribution, and reproduction in any medium, provided the original work is properly cited. 
to increase the quantity of type I collagen in bone matrix of ovariectomized (OVX) rats [11]. Moreover, in patients with osteoporosis, oral intake of $\mathrm{HC}$ in addition to injection of calcitonin had a stronger inhibitory effect on bone resorption than the injection of calcitonin alone [12]. These results suggest that dietary collagen peptides would effectively prevent age-related bone loss. However, it has not been demonstrated whether the intake of $\mathrm{HC}$ also has positive effect on bone mass or strength in growing bone.

Some studies have investigated the effects of the intake level of protein on bone mass. Protein deficiency could decrease the secretion of insulin-like growth factor 1 (IGF-1) [13], which may prevent normal growth of bone mass. Recently, we also demonstrated that a low protein intake suppressed the acquisition of bone mass and the increase of bone strength during growth period [14]. Conversely, a high protein intake results in higher urinary calcium (Ca) excretion, which may lead to accelerated bone resorption [15]. Similarly, we demonstrated that a high protein intake suppressed the increase of bone strength during growth period in which treadmill running was performed [14]. However, these studies used only casein protein as a protein source of the diet; it is not known whether $\mathrm{HC}$ intake included in a high protein diet has positive effect on bone mass or strength when combined with running exercise during growth phase.

Accordingly, the aim of this study is to investigate 1) the effect of $\mathrm{HC}$ intake alone and $\mathrm{HC}$ intake combined with treadmill running exercise on bone mass and strength in growing rats, 2) whether the intake of a high protein diet containing $\mathrm{HC}$ has a positive effect on bone mass and strength of growing rats trained with running exercise.

\section{Methods}

\section{Experimental animals and protocol}

Fifty-nine male Wistar rats, 5 weeks of age were obtained from CLEA Japan, Inc (Tokyo, Japan). Rats were randomized into four groups, the $20 \%$ casein group (Casein20), the $40 \%$ casein group (Casein 40 ), the 20\% HC group (HC20), and the 40\% HC group (HC40). Each group was further divided into exercise groups (Casein20 + Ex, Casein40 + Ex, HC20 + Ex, HC40 + Ex) and non-exercise groups (Casein20, Casein40, HC20, HC40) ( $n=7$ or 8 each). The experimental period was 11 weeks. The animals were individually housed at $23 \pm 1^{\circ} \mathrm{C}$ and humidity of $50 \pm 5 \%$ on an inverted $12 / 12 \mathrm{~h}$ light/dark cycle. All animals received food and water ad libitum. Body weight and food intake were measured at $48 \mathrm{~h}$ intervals throughout the experimental period. All experimental protocols in the present study were approved by the Committee on Animal Research at the University of Tsukuba.

\section{Experimental diets}

Each group received one of two levels of protein for its diet, $20 \%$ or $40 \%$ to total diet weight. Since the recommended dietary percentage of protein for growing animals is $17.9 \%$ [16], we used $20 \%$ protein as a moderate protein intake and $40 \%$ protein as a high protein intake. In the $\mathrm{HC}$ intake groups, $30 \%$ of casein protein was replaced with HC. Enzymatic $\mathrm{HC}$ was provided by JNC Corporation (Yokohama, Japan). The $\mathrm{HC}$ was of marine fish origin with a molecular weight of about $1 \mathrm{kDa}$. It was prepared with extraction by the enzymatic degradation. Then the extracted product was concentrated and dried. The product is powder with little taste and odor. All diets were controlled at $0.6 \%$ Calcium $(\mathrm{Ca})$ and $0.6 \%$ Phosphate (P). These diet compositions are described in Table 1.

\section{Exercise}

Exercise group rats were trained 6 days per week on a treadmill (KN-73, Natsume, Tokyo). The running speed and time were gradually increased $(10-25 \mathrm{~m} / \mathrm{min}, 10-$ $60 \mathrm{~min})$. Regular training started on the second week, and the running speed was further increased $(25-30 \mathrm{~m} / \mathrm{min})$. Finally, the rats ran for 60 consecutive minutes (27$30 \mathrm{~m} / \mathrm{min}$ ). The training period was 60 days. This running speed $(30 \mathrm{~m} / \mathrm{min})$ corresponds to $60 \sim 70 \% \mathrm{VO}_{2} \max$ for rats [17]. To this training was added a warm-up session $(15 \mathrm{~m} / \mathrm{min}, 5 \mathrm{~min})$ and a cool-down session $(15 \mathrm{~m} / \mathrm{min}$, $5 \mathrm{~min}$ ), making the total exercise time to 70 minutes.

\section{Dissection}

After 11 weeks (at 16 weeks of age), rats were fasted for $12 \mathrm{~h}$ and dissected. The femur, tibia and lumbar spine were collected, and cleaned of adjacent tissues. The length of femora was immediately measured, and stored at $4^{\circ} \mathrm{C}$ for later mechanical testing. The tibiae and lumbar spines were stored in $70 \%$ ethanol for bone mineral content assessment.

\section{Bone mineral content}

The BMC and area of lumbar spines and tibiae were analyzed by dual-energy X-ray absorptiometry (DXA: Aloka DCS-600R) [18].

\section{Femoral weights, length and mechanical testing}

Femoral length was measured with a precision caliper. The femoral breaking force and energy were measured by the three point bending method using a bone strength measuring apparatus (Iio Co., Japan) as described in a previous report [19]. Subsequently, the femora were dried at $100^{\circ} \mathrm{C}$ for $24 \mathrm{~h}$ in the electric furnace, and their dry weight were measured. Next, the dried femur were burned to ash at $600^{\circ} \mathrm{C}$ for $15 \mathrm{~h}$, and their ash weight were measured. The data of femoral breaking force and 
Table 1 Composition of experimental diets

\begin{tabular}{|c|c|c|c|c|}
\hline \multirow[t]{3}{*}{ Constituents } & \multicolumn{2}{|c|}{$20 \%$ Protein } & \multicolumn{2}{|c|}{$40 \%$ Protein } \\
\hline & collagen(-) & collagen(+) & collagen(-) & collagen(+) \\
\hline & $(0.6 \% \mathrm{Ca}, 0.6 \% \mathrm{P})$ & $(0.6 \% \mathrm{Ca}, 0.6 \% \mathrm{P})$ & $(0.6 \% \mathrm{Ca}, 0.6 \% \mathrm{P})$ & $(0.6 \% \mathrm{Ca}, 0.6 \% \mathrm{P})$ \\
\hline Glucose monohydrate & 60.4 & 60.3 & 40.8 & 40.6 \\
\hline Casein (Vitamin free) & 20.0 & 14.0 & 40.0 & 28.0 \\
\hline Hydrolyzed collagen & - & 6.0 & - & 12.0 \\
\hline Cystine & 0.2 & 0.2 & 0.2 & 0.2 \\
\hline Cottonseed oil & 10.0 & 10.0 & 10.0 & 10.0 \\
\hline $\mathrm{CaCO}_{3}$ & 1.4879 & 1.4777 & 1.4774 & 1.4734 \\
\hline $\mathrm{KH}_{2} \mathrm{PO}_{4}$ & 1.1424 & 0.9667 & 0.9666 & 1.0636 \\
\hline $\mathrm{K}_{2} \mathrm{HPO}_{4}$ & 1.4621 & 1.2373 & 1.2372 & 1.3613 \\
\hline Roughage & 3.0 & 3.0 & 3.0 & 3.0 \\
\hline Choline chloride & 0.2 & 0.2 & 0.2 & 0.2 \\
\hline Water soluble Vitamin mixture ${ }^{a)}$ & 0.1 & 0.1 & 0.1 & 0.1 \\
\hline Oil soluble Vitamin mixture & b) & b) & b) & b) \\
\hline Ca P free salt mixture ${ }^{c)}$ & 2.0 & 2.0 & 2.0 & 2.0 \\
\hline
\end{tabular}

a) The water soluble vitamin in mixture (in \%): thiamine, 0.5 ; riboflavin, 0.5 ; pyridoxine, 0.5 ; calcium pantothenate, 2.8; nicotinamide, 2.0; inositol, 20.0; B12, 0.002; foric acid, 0.2; vitamin biotin, 0.01 ; and glucose monohydrate, 3.7 .

${ }^{c}$ The Calcium (Ca) Phosphorus (P) free salt mixture (in \%): potassium chloride,57.7; sodium chloride,20.9;magnesium sulfate,anhydrous,17.9; copper(II)sulfate pentahydrate, 0.078 ; sodium fluoride, 0.113 ; cobalt(II)chloride, 0.004 ; potassium lodide, 0.01 ; magnese(II)sulfate pentahydrate, 0.06 ; hexaammonium heptamolybdate tetrahydrate,0.005; iron(II)sulfate heptahydrate,3.22;zinc sulfate heptahydrate, 0.44 .

energy were adjusted to the dry weight (the adjusted breaking force and energy) to exclude the influence of body mass.

\section{Bone metabolic marker}

Serum bone-specific alkaline phosphatase (BAP) activity, the bone mineralization parameters and tartrate-resistant acid phosphatase (TRAP) activity, and the bone resorption markers were determined as previously reported [20].

\section{Statistical methods}

The results are expressed as the mean \pm standard error of the mean (SE) and were analyzed with SPSS (version 21.0 J; SPSS Inc., Chicago, IL, USA). The data were analyzed using a two-way analysis of variance (ANOVA). Moreover, $t$-test was performed on four pairs of $20 \%$ protein groups and $40 \%$ protein groups of the same diet and physical activity to assess significant difference between the moderate and the higher protein groups (Casein $20 \times$ Casein40, Casein $20+\mathrm{Ex} \times$ Casein $40+\mathrm{Ex}, \mathrm{HC} 20 \times \mathrm{HC} 40$, $\mathrm{HC} 20+\mathrm{Ex} \times \mathrm{HC} 40+\mathrm{Ex})$. Statistical significance was taken at the $\mathrm{p}<0.05$ level.

\section{Results}

\section{Food intake and body weight}

At the beginning of the experiment, body weight did not differ among the groups. In the food intake during experiment, exercise effect was obtained $(\mathrm{p}<0.001)$, and was significantly lower in the exercise groups than in the sedentary groups. These effects were detected both among the $20 \%$ protein groups and the $40 \%$ protein groups (Table 2). Therefore, the body weight gain, the food efficiency, and the final body weight were significantly lower in the exercise groups than in the sedentary groups ( $\mathrm{p}<0.001$, respectively). Dietary $\mathrm{HC}$ effect was not obtained in these data among the $20 \%$ protein groups, but the effect was obtained in the food intake, the body weight gain, the food efficiency, and the final body weight among the $40 \%$ protein groups $(\mathrm{p}<0.05, \mathrm{p}<0.01$, $\mathrm{p}<0.05$ and $\mathrm{p}<0.05$, respectively, casein groups $>\mathrm{HC}$ groups) (Table 2 ). The food intake was significantly higher in the Casein20, HC20, and HC20 + Ex groups than the Casein40 (p<0.01), HC40 ( $<<0.01)$ and HC40 + Ex groups $(\mathrm{p}<0.05$, respectively) (Table 2$)$.

\section{BMC}

Exercise and dietary $\mathrm{HC}$ effects were obtained in the adjusted BMC of lumbar spine, tibia proximal metaphysis, and tibia diaphysis among the $20 \%$ protein groups ( $p<0.001$ for exercise, $\mathrm{p}<0.05$ for dietary $\mathrm{HC}$, respectively). These adjusted BMC values were significantly higher in the exercise groups than those in the sedentary groups, and were also significantly higher in the $\mathrm{HC}$ groups than those in the casein groups. Among the 40\% protein groups, similar results were obtained except for tibia diaphysis ( $p<0.01$ for exercise; $\mathrm{p}<0.05$ for dietary $\mathrm{HC}$, respectively) (Figure 1). There were no differences between the $20 \%$ protein groups and the $40 \%$ protein groups. 
Table 2 Body weight, body weight gain, food intake, energy intake, and food efficiency

\begin{tabular}{|c|c|c|c|c|c|c|c|c|c|}
\hline & & \multirow{2}{*}{$20 \%$ protein } & \multicolumn{3}{|c|}{ Two-way ANOVA (p value) } & \multirow{2}{*}{$40 \%$ protein } & \multicolumn{3}{|c|}{ Two-way ANOVA ( $p$ value) } \\
\hline & & & Exercise & Collagen & Interaction & & Exercise & Collagen & Interaction \\
\hline \multicolumn{10}{|c|}{ Initial body weight (g) } \\
\hline Collagen(-) & EX(-) & $115.3 \pm 0.9$ & \multirow{4}{*}{0.739} & \multirow{4}{*}{0.665} & \multirow{4}{*}{0.787} & $113.7 \pm 2.1$ & \multirow{4}{*}{0.759} & \multirow{4}{*}{0.218} & \multirow{4}{*}{0.240} \\
\hline \multirow{3}{*}{ Collagen(+) } & $\mathrm{EX}(+)$ & $116.1 \pm 1.5$ & & & & $115.5 \pm 0.7$ & & & \\
\hline & EX(-) & $116.3 \pm 1.6$ & & & & $116.6 \pm 1.2$ & & & \\
\hline & $\mathrm{EX}(+)$ & $116.4 \pm 1.8$ & & & & $115.6 \pm 0.6$ & & & \\
\hline \multicolumn{10}{|c|}{ Final body weight (g) } \\
\hline Collagen(-) & EX(-) & $405.3 \pm 5.5$ & \multirow{4}{*}{$<0.001$} & \multirow{4}{*}{0.250} & \multirow{4}{*}{0.350} & $411.7 \pm 8.8$ & \multirow{4}{*}{$<0.001$} & \multirow{4}{*}{0.014} & \multirow{4}{*}{0.903} \\
\hline \multirow{3}{*}{ Collagen(+) } & $\mathrm{EX}(+)$ & $342.0 \pm 7.2$ & & & & $354.1 \pm 8.5$ & & & \\
\hline & EX(-) & $391.0 \pm 8.5$ & & & & $391.5 \pm 5.4$ & & & \\
\hline & $\mathrm{EX}(+)$ & $340.5 \pm 7.3$ & & & & $335.7 \pm 8.7$ & & & \\
\hline \multicolumn{10}{|c|}{ Body weight gain (g/d) } \\
\hline \multirow[t]{2}{*}{ Collagen(-) } & EX(-) & $4.0 \pm 0.1$ & \multirow{4}{*}{$<0.001$} & \multirow{4}{*}{0.189} & \multirow{4}{*}{0.259} & $4.1 \pm 0.1$ & \multirow{4}{*}{$<0.001$} & \multirow{4}{*}{0.006} & \multirow{4}{*}{0.758} \\
\hline & $\mathrm{EX}(+)$ & $3.1 \pm 0.1$ & & & & $3.2 \pm 0.1$ & & & \\
\hline \multirow[t]{2}{*}{ Collagen(+) } & EX(-) & $3.7 \pm 0.1$ & & & & $3.7 \pm 0.1$ & & & \\
\hline & $\mathrm{EX}(+)$ & $3.0 \pm 0.1$ & & & & $3.0 \pm 0.1$ & & & \\
\hline \multicolumn{10}{|c|}{ Food intake $(\mathrm{g} / \mathrm{d})$} \\
\hline \multirow[t]{2}{*}{ Collagen(-) } & EX(-) & $20.9 \pm 0.2$ & & & & $19.9 \pm 0.2^{* *}$ & & & \\
\hline & $\mathrm{EX}(+)$ & $18.2 \pm 0.4$ & $<0001$ & (15) & 0147 & $17.9 \pm 0.3$ & $<0001$ & 0019 & 0712 \\
\hline Collagen(+) & EX(-) & $20.2 \pm 0.2$ & $<0.001$ & 0.215 & 0.147 & $19.3 \pm 0.2^{* *}$ & $<0.001$ & 0.019 & 0.112 \\
\hline & $\mathrm{EX}(+)$ & $18.3 \pm 0.3$ & & & & $17.5 \pm 0.12^{*}$ & & & \\
\hline Food efficiency & & & & & & & & & \\
\hline Collagen(-) & EX(-) & $0.19 \pm 0.00$ & & & & $0.20 \pm 0.00^{* *}$ & & & \\
\hline & $\mathrm{EX}(+)$ & $0.17 \pm 0.00$ & $<0001$ & 0234 & 0784 & $0.18 \pm 0.00^{*}$ & $<0001$ & 0.028 & 0.926 \\
\hline Collagen(+) & EX(-) & $0.18 \pm 0.01$ & $=0.00$ & 0.221 & (2.7 & $0.19 \pm 0.00$ & $=0.001$ & 0.020 & 0.020 \\
\hline & $\mathrm{EX}(+)$ & $0.16 \pm 0.00$ & & & & $0.17 \pm 0.01$ & & & \\
\hline
\end{tabular}

${ }^{1}$ Food efficiency was calculated by Body weight gain (g/d)/Food intake (g/d). EX(-): sedentary group, EX(+): exercise group.

Values are expressed as means \pm SE. Data were analyzed by two-way ANOVA at the $5 \%$ level of significance. Interaction means Exercise-Collagen interaction. ${ }^{*} p<0.05$ and ${ }^{*} p<0.01$ vs. respective $20 \%$ protein group.

\section{Femoral weights and length}

Exercise and dietary $\mathrm{HC}$ effects were obtained in the adjusted wet weight and dry weight of femur among the $20 \%$ protein groups $(\mathrm{p}<0.001, \mathrm{p}<0.01$ for exercise; $\mathrm{p}<0.01$, $\mathrm{p}<0.001$ for dietary $\mathrm{HC}$, respectively). In the adjusted ash weight, exercise effect was obtained among the $20 \%$ protein groups $(\mathrm{p}<0.001)$. Among the $40 \%$ protein groups, similar results were obtained for exercise $(p<0.001$, respectively) and for dietary $\mathrm{HC}(\mathrm{p}<0.01, \mathrm{p}<0.001, \mathrm{p}<0.01$, respectively) (Table 3 ). There were no differences between the $20 \%$ protein groups and the $40 \%$ protein groups. In femoral length, the exercise groups were lower than the sedentary groups in both the $20 \%$ protein groups and the $40 \%$ protein groups, and exercise effect was obtained among the $20 \%$ protein groups $(\mathrm{p}<0.01)$ (Table 3$)$. Dietary $\mathrm{HC}$ effect was not obtained in femoral length both among the $20 \%$ protein groups and the $40 \%$ protein groups.
Bone breaking force and energy of femur

Among the $20 \%$ protein groups, exercise effect was obtained in the adjusted femoral breaking force and energy ( $\mathrm{p}<0.01$, respectively) and the exercise groups were significantly higher than those in the sedentary groups, whereas dietary HC effect was not significant (Table 4). Similarly, among the $40 \%$ protein groups, exercise effect was only obtained in the adjusted femoral breaking force and energy ( $\mathrm{p}<0.01$ for adjusted breaking force; $\mathrm{p}<0.05$ for adjusted breaking energy), and dietary $\mathrm{HC}$ effect was not significant (Table 4). There were no differences in both the adjusted femoral breaking force and energy between the $20 \%$ protein groups and the $40 \%$ protein groups.

\section{Bone metabolic marker}

BAP activity did not differ among the $20 \%$ protein groups (Casein20: $38.70 \pm 15.20 U / L$, Casein20 + Ex: $55.28 \pm$ 


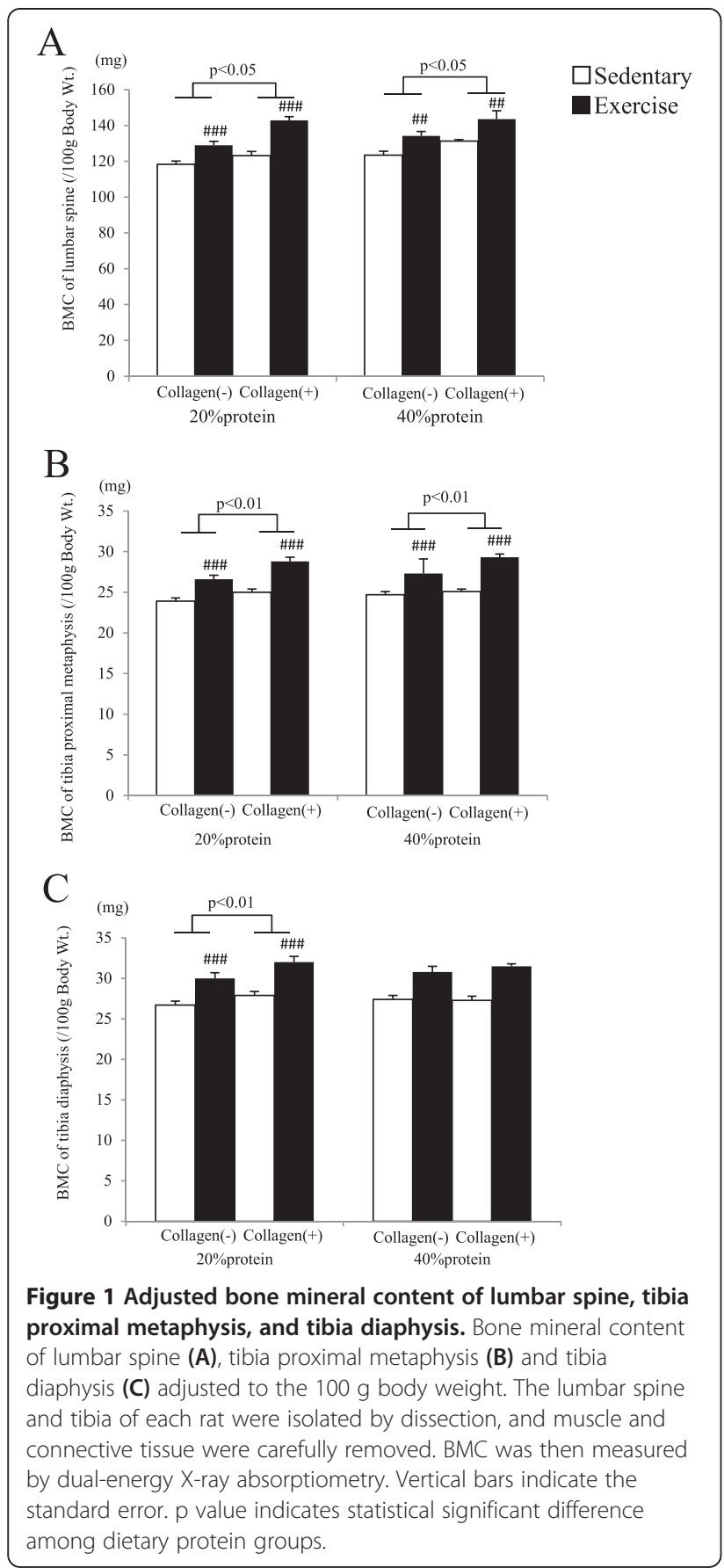

12.14U/L, HC20: $33.91 \pm 8.91 \mathrm{U} / \mathrm{L}, \mathrm{HC} 20+\mathrm{Ex}: 33.91 \pm$ $10.16 \mathrm{U} / \mathrm{l})$. Similarly, among the $40 \%$ protein groups, there were no differences (Casein40: $35.75 \pm 8.69 \mathrm{U} / \mathrm{l}$, Casein40 + Ex: $38.14 \pm 10.01 \mathrm{U} / \mathrm{l}, \quad \mathrm{HC} 40: \quad 33.31 \pm 7.90 \mathrm{U} / \mathrm{l}$, HC40 + Ex: $37.66 \pm 7.58 \mathrm{U} / \mathrm{l})$. Moreover, TRAP activity did not also differ among the $20 \%$ and $40 \%$ protein groups, respectively (Casein20: 19.39 $\pm 2.11 \mathrm{U} / \mathrm{L}$, Casein20 + Ex: $24.59 \pm 3.36 \mathrm{U} / \mathrm{L}, \mathrm{HC} 20: 17.75 \pm 3.97 \mathrm{U} / \mathrm{L}, \mathrm{HC} 20+\mathrm{Ex}:$ $18.81 \pm 2.20 \mathrm{U} / \mathrm{L}$, Casein40: $19.65 \pm 1.27 \mathrm{U} / \mathrm{L}$, Casein $40+$ Ex: $22.10 \pm 4.47 \mathrm{U} / \mathrm{L}, \mathrm{HC} 40: 20.47 \pm 1.43 \mathrm{U} / \mathrm{L}, \mathrm{HC} 40+\mathrm{Ex}$ :
$21.75 \pm 1.67 \mathrm{U} / \mathrm{L})$. In these two bone metabolic markers, there were no differences between the $20 \%$ protein groups and the $40 \%$ protein groups.

\section{Discussion}

We investigated the effects of $\mathrm{HC}$ intake and treadmill running exercise on bone mass and strength in growing male rats. This study demonstrated that $\mathrm{HC}$ intake increases bone mass in both trained and untrained growing rats. Although these results were shown in both moderate and high protein intake groups, the level of these beneficial effects on bone mass was similar for the two groups. The intake of a high protein diet containing $\mathrm{HC}$ may have no more beneficial effect on bone mass and strength on growing rats trained with running exercise than the intake of a moderate protein diet containing $\mathrm{HC}$.

In the present study, we showed the effect of $\mathrm{HC}$ intake and treadmill running exercise on adjusted BMC of lumbar spine and tibia. The adjusted BMC was higher in the exercise groups (Casein20 + Ex, Casein40 + Ex, HC20 + Ex, and $\mathrm{HC} 40+\mathrm{Ex}$ ) than in the sedentary groups (Casein20, Casein40, HC20, and HC40). Especially in the trained $\mathrm{HC}$ intake groups $(\mathrm{HC} 20+\mathrm{Ex}, \mathrm{HC} 40+\mathrm{Ex})$, those effects were strongly observed. Guillerminet et al. [21] had shown that the BMD for OVX mice fed with the diet including $\mathrm{HC}$ (porcine origin) was significantly higher as compared to OVX mice fed on a standard AIN-93N diet. Mizoguchi et al. [22] had also shown that the HC (marine fish origin) intake increased the level of serum osteocalcin (OC), a well-known marker of osteogenesis, along with the BMD and the bone strength of femur in OVX rats. The levels of serum hydroxyproline and glycine of the $\mathrm{HC}$ intake group were increased in those cases. These results suggest that dietary $\mathrm{HC}$ intake increases the level of serum amino acid (hydroxyproline and glycine), the important components of bone, which then increases the BMD and bone strength. Moreover, in vitro study, hydrolyzed collagens (bovine, porcine, and fish origin, respectively having a molecular weight of 2 or $5 \mathrm{kDa}$ ) in osteoblasts had significant and dose-dependent increase in ALP activity, a well-known marker of osteogenesis [23]. These results suggest that dietary hydrolyzed collagen may increase bone formation. Although, our result did not show the difference of bone formation marker, we cautiously postulated that the beneficial effect of $\mathrm{HC}$ intake in this study could have acted on bone during growth phase since we assessed the bone markers by end-point experiment when being already adult bone. Taken together, these results suggest that $\mathrm{HC}$ intake has a beneficial effect on bone mass in growing rats and this effect is more beneficial for rats participating in treadmill running exercise.

Our study also investigated whether the intake of a high protein diet containing $\mathrm{HC}$ has positive effects on bone mass and strength of growing rats trained with 
Table 3 Femoral weights and length

\section{$20 \%$ protein}

Wet weight (g)

$\begin{array}{ccc}\text { Collagen(-) } & \text { EX(-) } & 0.9860 \pm 0.0010 \\ & \text { EX(+) } & 0.9633 \pm 0.0290 \\ \text { Collagen(+) } & \text { EX(-) } & 1.0191 \pm 0.0215 \\ & \text { EX(+) } & 0.9910 \pm 0.0145\end{array}$

Wet weight (g/100g Body Wt.)

$\begin{array}{ccc}\text { Collagen(-) } & \text { EX(-) } & 0.2434 \pm 0.0026 \\ & \text { EX(+) } & 0.2796 \pm 0.0077 \\ \text { Collagen(+) } & \text { EX(-) } & 0.2605 \pm 0.0032 \\ & \text { EX(+) } & 0.2918 \pm 0.0057\end{array}$

Dry weight (g)

$\begin{array}{ccc}\text { Collagen(-) } & \text { EX(-) } & 0.6363 \pm 0.0088 \\ & \text { EX(+) } & 0.6031 \pm 0.0110 \\ \text { Collagen(+) } & \text { EX(-) } & 0.6450 \pm 0.0142 \\ & \text { EX(+) } & 0.6247 \pm 0.0088\end{array}$

Dry weight (g/100g Body Wt.)

$\begin{array}{ccc}\text { Collagen(-) } & \text { EX(-) } & 0.1570 \pm 0.0021 \\ & \text { EX(+) } & 0.1751 \pm 0.0027 \\ \text { Collagen(+) } & \text { EX(-) } & 0.1649 \pm 0.0021 \\ & \text { EX(+) } & 0.1838 \pm 0.0028\end{array}$

Ash weight (g)

$\begin{array}{ccc}\text { Collagen(-) } & \text { EX(-) } & 0.3981 \pm 0.0109 \\ & \text { EX(+) } & 0.3793 \pm 0.0117 \\ \text { Collagen(+) } & \text { EX(-) } & 0.3998 \pm 0.0128 \\ & \text { EX(+) } & 0.3899 \pm 0.0108\end{array}$

Ash weight (g/100g Body Wt.)

$\begin{array}{ccc}\text { Collagen(-) } & \text { EX(-) } & 0.0982 \pm 0.0016 \\ & \text { EX(+) } & 0.1101 \pm 0.0026 \\ \text { Collagen(+) } & \text { EX(-) } & 0.1022 \pm 0.0016 \\ & \text { EX(+) } & 0.1147 \pm 0.0034\end{array}$

$\begin{array}{lll}0.013 & 0.152 & 0.540\end{array}$

$0.001<0.001 \quad 0.851$

$<0.001 \quad 0.095 \quad 0.896$

Ash weight (g/Dry weight)

$\begin{array}{ccc}\text { Collagen(-) } & \text { EX(-) } & 0.6252 \pm 0.0069 \\ & \text { EX(+) } & 0.6287 \pm 0.0042 \\ \text { Collagen(+) } & \text { EX(-) } & 0.6200 \pm 0.0044 \\ & \text { EX(+) } & 0.6237 \pm 0.0083\end{array}$

Length (cm)

$\begin{array}{ccc}\text { Collagen(-) } & \text { EX(-) } & 3.710 \pm 0.014 \\ & \text { EX(+) } & 3.623 \pm 0.023 \\ \text { Collagen(+) } & \text { EX(-) } & 3.699 \pm 0.017 \\ & \text { EX(+) } & 3.675 \pm 0.018\end{array}$

$\begin{array}{lll}0.553 & 0.396 \quad 0.985\end{array}$

$0.1044 \pm 0.0012$

$0.1215 \pm 0.0034$

$0.6310 \pm 0.0033$

$0.6413 \pm 0.0094$

$0.6313 \pm 0.0038$

$0.6347 \pm 0.0037$

$3.696 \pm 0.015$

$\begin{array}{lll}0.004 & 0.216 & 0.109\end{array}$

$3.646 \pm 0.009$
$0.6401 \pm 0.0126$

$0.6202 \pm 0.0075$

$0.6475 \pm 0.0082$

$0.6436 \pm 0.0199$

$0.1556 \pm 0.0028$

$0.1769 \pm 0.0021$

$0.1654 \pm 0.0016$

$0.1915 \pm 0.0040$

$0.4040 \pm 0.0125$

$0.3972 \pm 0.0037$

$0.4086 \pm 0.0071$

$0.4083 \pm 0.0175$

$0.0982 \pm 0.0027$

$0.1134 \pm 0.0024$

Two-way ANOVA ( $p$ value)

Exercise Collagen Interaction

$\begin{array}{lll}0.326 & 0.570 \quad 0.271\end{array}$

$\begin{array}{lll}<0.001 & 0.001 \quad 0.191\end{array}$

$\begin{array}{lll}0.327 & 0.207 & 0.508\end{array}$

$<0.001<0.001 \quad 0.365$

$\begin{array}{lll}0.726 & 0.442 & 0.751\end{array}$

$\begin{array}{lll}<0.001 & 0.005 \quad 0.688\end{array}$

$\begin{array}{lll}0.223 & 0.577 \quad 0.540\end{array}$

$3.668 \pm 0.010$

$\begin{array}{lll}0.084 & 0.851 \quad 0.082\end{array}$ 
Table 3 Femoral weights and length (Continued)

\begin{tabular}{|c|c|c|c|c|c|c|c|c|c|}
\hline \multicolumn{10}{|l|}{ Long Width (cm) } \\
\hline Collagen(-) & $E X(-)$ & $0.440 \pm 0.005$ & \multirow{4}{*}{0.848} & \multirow{4}{*}{0.266} & \multirow{4}{*}{0.722} & $0.441 \pm 0.005$ & \multirow{4}{*}{1.000} & \multirow{4}{*}{0.035} & \multirow{4}{*}{$0.339 \mid$} \\
\hline & $E X(+)$ & $0.438 \pm 0.004$ & & & & $0.436 \pm 0.003$ & & & \\
\hline \multirow[t]{2}{*}{ Collagen(+) } & $E X(-)$ & $0.444 \pm 0.006$ & & & & $0.446 \pm 0.005$ & & & \\
\hline & EX(+) & $0.445 \pm 0.005$ & & & & $0.451 \pm 0.006$ & & & \\
\hline \multicolumn{10}{|l|}{ Short Width (cm) } \\
\hline \multirow[t]{2}{*}{ Collagen(-) } & EX(-) & $0.352 \pm 0.004$ & \multirow{4}{*}{0.169} & \multirow{4}{*}{0.328} & \multirow{4}{*}{0.591} & $0.348 \pm 0.005$ & \multirow{4}{*}{0.121} & \multirow{4}{*}{0.385} & \multirow{4}{*}{0.746} \\
\hline & EX(+) & $0.345 \pm 0.003$ & & & & $0.344 \pm 0.002$ & & & \\
\hline \multirow[t]{2}{*}{ Collagen(+) } & EX(-) & $0.346 \pm 0.004$ & & & & $0.353 \pm 0.003$ & & & \\
\hline & EX(+) & $0.343 \pm 0.003$ & & & & $0.346 \pm 0.005$ & & & \\
\hline
\end{tabular}

Values are expressed d as means $\pm \mathrm{SE}$. Data were analyzed by two-way ANOVA at the $5 \%$ level of significance. Interaction means Exercise-Collagen interaction.

running exercise. Although the adjusted BMC of lumbar spine and tibia were significantly higher in the $\mathrm{HC}$ groups than in the casein groups among both the 20\% protein groups and the $40 \%$ protein groups, the dietary $\mathrm{HC}$ effect had no dose-dependent increase. In the previous study, we had shown that a high protein, two times the $20 \%$ moderate casein intake, had no positive effect on bone mass and strength in growing rats [14]. Moreover, in this study, the intake of a high protein diet containing $\mathrm{HC}$ also had no more beneficial effect than a moderate protein diet containing $\mathrm{HC}$ on bone mass and strength in growing rats. These results suggest that the beneficial effect of $\mathrm{HC}$ intake on increasing bone mass may have been limited.

Interestingly, the beneficial effect of $\mathrm{HC}$ intake was not observed on bone strength. Seventy percent of bone strength depends on its density and 30\% depends on its quality [24]. The bone quality is determined by the degree

Table 4 Breaking force and energy of the femoral diaphysis

\begin{tabular}{|c|c|c|c|c|c|c|c|c|c|}
\hline & & \multirow{2}{*}{$20 \%$ protein } & \multicolumn{3}{|c|}{ Two-way ANOVA ( $p$ value) } & \multirow{2}{*}{$40 \%$ protein } & \multicolumn{3}{|c|}{ Two-way ANOVA ( $p$ value) } \\
\hline & & & Exercise & Collagen & Interaction & & Exercise & Collagen & Interaction \\
\hline \multicolumn{10}{|l|}{ Breaking force $\left(\times 10^{6}\right.$ dyn $)$} \\
\hline \multirow{4}{*}{ Collagen(+) } & $\mathrm{EX}(-)$ & $29.358 \pm 1.396$ & \multirow{4}{*}{0.574} & \multirow{4}{*}{0.523} & \multirow{4}{*}{0.068} & $27.864 \pm 1.105$ & \multirow{4}{*}{0.757} & \multirow{4}{*}{0.708} & \multirow{4}{*}{0.547} \\
\hline & $\mathrm{EX}(+)$ & $26.702 \pm 0.928$ & & & & $29.132 \pm 1.994$ & & & \\
\hline & EX(-) & $26.618 \pm 1.358$ & & & & $29.222 \pm 1.101$ & & & \\
\hline & $\mathrm{EX}(+)$ & $28.037 \pm 0.803$ & & & & $28.816 \pm 1.255$ & & & \\
\hline \multicolumn{10}{|c|}{ Breaking force $\left(\times 10^{6} \text { dyn/100g Body Wt. }\right)^{1}$} \\
\hline Collagen(-) & EX(-) & $7.234 \pm 0.329$ & \multirow{4}{*}{0.001} & \multirow{4}{*}{0.909} & \multirow{4}{*}{0.082} & $6.766 \pm 0.227$ & \multirow{4}{*}{0.002} & \multirow{4}{*}{0.274} & \multirow{4}{*}{0.605} \\
\hline & $\mathrm{EX}(+)$ & $7.741 \pm 0.231$ & & & & $8.343 \pm 0.179$ & & & \\
\hline \multirow[t]{2}{*}{ Collagen(+) } & EX(-) & $6.798 \pm 0.31$ & & & & $7.455 \pm 0.254$ & & & \\
\hline & $\mathrm{EX}(+)$ & $8.237 \pm 0.218$ & & & & $8.591 \pm 0.352$ & & & \\
\hline \multicolumn{10}{|l|}{ Breaking energy $\left(\times 10^{5}\right.$ erg) } \\
\hline \multirow{4}{*}{ Collagen(+) } & EX(-) & $20.301 \pm 1.598$ & \multirow{4}{*}{0.458} & \multirow{4}{*}{0.919} & \multirow{4}{*}{0.182} & $17.202 \pm 1.778$ & \multirow{4}{*}{0.492} & \multirow{4}{*}{0.195} & \multirow{4}{*}{0.145} \\
\hline & $\mathrm{EX}(+)$ & $19.430 \pm 1.116$ & & & & $20.546 \pm 1.048$ & & & \\
\hline & EX(-) & $18.203 \pm 1.704$ & & & & $21.499 \pm 1.280$ & & & \\
\hline & $\mathrm{EX}(+)$ & $21.231 \pm 1.480$ & & & & $20.290 \pm 1.982$ & & & \\
\hline \multicolumn{10}{|c|}{ Breaking energy $\left(\times 10^{5} \text { erg/100d Body Wt. }\right)^{1}$} \\
\hline \multirow[t]{2}{*}{ Collagen(-) } & EX(-) & $4.987 \pm 0.37$ & \multirow{4}{*}{0.002} & \multirow{4}{*}{0.886} & \multirow{4}{*}{0.269} & $4.191 \pm 0.436$ & & & \\
\hline & EX(+) & $5.758 \pm 0.221$ & & & & $5.833 \pm 0.296$ & م100م & م>0 & م100 \\
\hline Collagen(+) & EX(-) & $4.644 \pm 0.407$ & & & & $5.496 \pm 0.376$ & 0.010 & 0.070 & .190 \\
\hline & $\mathrm{EX}(+)$ & $6.202 \pm 0.389$ & & & & $6.047 \pm 0.569$ & & & \\
\hline
\end{tabular}

Values are expressed as means \pm SD. Data were analyzed by two-way ANOVA at the $5 \%$ level of significance. Interaction means Exercise-Collagen interaction. ${ }^{1}$ Breaking force and energy adjusted to the $100 \mathrm{~g}$ body weight to exclude the influence of body mass. 
of bone mineralization, microdamage accumulation, bone size, collagen crosslinks formation and bone turnover rate [25]. Thus, the reason for the same level of bone strength between the casein groups and the $\mathrm{HC}$ intake groups despite the higher level of bone mass in the $\mathrm{HC}$ intake groups than in the casein intake groups might be in the bone quality difference. Mizoguchi et al. had investigated that mineral and collagen derived from fish-skin supplementation tend to improve bone strength in OVX rats [26]. On the other hand, there are very few studies investigating the effect of $\mathrm{HC}$ intake on bone strength during growth phase. Our data suggest that the effect of $\mathrm{HC}$ intake may change in different bone statuses. More investigation is necessary to discuss the effect of $\mathrm{HC}$ intake on bone quality and strength.

Our study had several limitations. The food intake and final body weight were significantly lower in the exercise groups than in the sedentary groups. Moreover, among the $40 \%$ protein groups, these data were significantly lower in the $\mathrm{HC}$ intake groups than in the casein intake groups. Growth of bone is considerably influenced by body mass [27]. Therefore, we were unable to precisely describe the relation of weight-related growth and benefits of physical exercise. Moreover, we had investigated the effect of $\mathrm{HC}$ intake by exchanging a part of casein with $\mathrm{HC}$ ( $30 \%$ of protein was HC). Therefore, the amount of carbohydrate and essential amino acids were different between $20 \%$ protein diet and $40 \%$ protein diet. This may have had some effect on the results of our previous study. Further research is needed to assess the effect of $\mathrm{HC}$ intake in conditions where the amount of other nutrition is adjusted.

In summary, the present study demonstrated that moderate $\mathrm{HC}$ intake (where the diet contains $20 \%$ protein, of which $30 \%$ is $\mathrm{HC}$ ) increased bone mass during growth periods and further promoted the effect of running exercise. On the other hand, a high protein diet containing $\mathrm{HC}$ (where the diet contains $40 \%$ protein, of which $30 \%$ is $\mathrm{HC}$ ) had no more beneficial effect on bone mass than the moderate protein intake. These results could be of potential interest for new nutritional support in the increasing effect of physical exercise on bone mass during growth.

Competing interests

The authors declare no competing interests.

\section{Authors' contributions}

ST conceived of the study and carried out: 1) study design, 2) data collection, 3) data analysis, 4) statistical analysis and 5) preparing manuscript. JHP assisted in 1) data analysis and 2) preparing the manuscript. EK assisted in 1) study design and 2) data collection. IE assisted in coordination and helped to draft the manuscript. NO procured grant funding and assisted in: 1) study design, 2) data collection and analysis, and 3) preparing the manuscript. All authors read and approved the final manuscript.

\section{Acknowledgements}

The authors are grateful to all of the members of the Exercise and Nutrition Laboratory at the University of Tsukuba for their kind cooperation in the anatomy work. PARK, JH is supported by Japan Society for the Promotion of Science (JSPS).

\section{Author details}

'Graduate School of Comprehensive Human Sciences, University of Tsukuba, Ibaraki, Japan. ${ }^{2}$ Center for Disease Biology and Integrative Medicine, University of Tokyo, Tokyo, Japan. ${ }^{3}$ Department of Physical Education, Konkuk University, Seoul, South Korea. ${ }^{4}$ Yokohama Research Center, JNC Corporation, Yokohama, Japan. ${ }^{5}$ Japan Women's University, Tokyo, Japan. ${ }^{6}$ Faculty of Health and Sport Sciences, University of Tsukuba, Ibaraki, Japan. ${ }^{7}$ Institute of Health and Sports Sciences, Graduate School of Comprehensive Human Sciences, University of Tsukuba, Tsukuba, Ibaraki 305-8574, Japan.

Received: 22 March 2013 Accepted: 1 August 2013

Published: 6 August 2013

\section{References}

1. Hind K, Burrows M: Weight-bearing exercise and bone mineral accrual in children and adolescents: a review of controlled trials. Bone 2007, 40(1):14-27.

2. Chevalley T, Bonjour JP, Ferrari S, Rizzoli R: High-protein intake enhances the positive impact of physical activity on BMC in prepubertal boys, J Bone Miner Res 2008, 23(1):131-142.

3. Carlsohn A, Cassel M, Linne K, Mayer F: How much is too much? A case report of nutritional supplement use of a high-performance athlete. Br J Nutr 2011, 25:1-5.

4. Oishi Y, Fu ZW, Ohnuki Y, Kato H, Noguchi T: Molecular basis of the alteration in skin collagen metabolism in response to in vivo dexamethasone treatment: effects on the synthesis of collagen type I and III, collagenase, and tissue inhibitors of metalloproteinases. Br J Dermatol 2002, 147(5):859-868.

5. Takeuchi Y, Nakayama K, Matsumoto T: Differentiation and cell surface expression of transforming growth factor-beta receptors are regulated by interaction with matrix collagen in murine osteoblastic cells. J Biol Chem 1996, 271(7):3938-3944.

6. Takeuchi Y, Suzawa M, Kikuchi T, Nishida E, Fujita T, Matsumoto T: Differentiation and transforming growth factor-beta receptor downregulation by collagen-alpha2beta 1 integrin interaction is mediated by focal adhesion kinase and its downstream signals in murine osteoblastic cells. J Biol Chem 1997, 272(46):29309-29316.

7. Gaffney PJ, Edgell TA, Dawson PA, Ford AW, Stocker E: A pig collagen peptide fraction. A unique material for maintaining biological activity during lyophilization and during storage in the liquid state. J Pharm Pharmacol 1996, 48(9):896-898.

8. Khare SD, Krco CJ, Griffiths MM, Luthara HS, David CS: Oral administration of an immunodominant human collagen peptide modulates collageninduced arthritis. J Immunol 1995, 155(7):3653-3659.

9. Ku G, Kronenberg M, Peacock DJ, Tempst P, Banquerigo ML, Braun BS, Reeve JR Jr, Brahn E: Prevention of experimental autoimmune arthritis with a peptide fragment of type II collagen. Eur J Immunol 1993, 23(3):591-599.

10. Wu J, Fujioka M, Sugimoto K, Mu G, Ishimi Y: Assessment of effectiveness of oral administration of collagen peptide on bone metabolism in growing and mature rats. J Bone Miner Metab 2004, 22(6):547-553.

11. Nomura Y, Oohashi K, Watanabe M, Kasugai S: Increase in bone mineral density through oral administration of shark gelatin to ovariectomized rats. Nutrition 2005, 21(11-12):1120-1126.

12. Adam M, Spacek P, Hulejová H, Galiánová A, Blahos J: Postmenopausal osteoporosis. Treatment with calcitonin and a diet rich in collagen proteins. Cas Lek Cesk 1996, 135(3):74-78.

13. Yahya ZA, Bates PC, Millward DJ: Responses to protein deficiency of plasma and tissue insulin-like growth factor-l levels and proteoglycan synthesis rates in rat skeletal muscle and bone. J Endocrinol 1990, 127(3):497-503.

14. Takeda S, Kobayashi Y, Park JH, Ezawa I, Omi N: Effect of different levels of dietary protein and physical exercise on bone mineral density and bone strength in growing male rats. J Nutr Sci Vitaminol 2012, 58(4):240-246

15. Jenkins DJ, Kendall CW, Vidgen E, Augustin LS, Parker T, Faulkner D, Vieth $R$, Vandenbroucke AC, Josse RG: Effect of high vegetable protein diets on urinary calcium loss in middle-aged men and women. Eur $J$ Clin Nutr 2003, 57(2):376-382. 
16. Reeves PG, Nielsen FH, Fahey GC Jr: AIN-93 purified diets for laboratory rodents: final report of the American Institute of Nutrition ad hoc writing committee on the reformulation of the AIN-76A rodent diet. J Nutr 1993, 123(11):1939-1951.

17. Wheeler DL, Graves JE, Miller GL, Vander-Griend RE, Wronski TJ, Powers SK, Park HM: Effects of running in the torisional strength, morphometry, and bone mass of the rat skeleton. Med Sci Sports Exerc 1995, 27(4):520-529.

18. Omi N, Tsukahara N, Ezawa I: Effect of milk on bone metabolism in growing male and female rats. J Home Econ Jpn 2001, 52(8):689-698.

19. Ezawa I, Okada R, Nozaki Y, Ogata E: Breaking-properties and ash contents of the femur of growing rat fed a low calcium diet. J Jpn Soc Food Nutr 1979, 32(5):329-335.

20. Omi N, Goseki M, Oida S, Sasaki S, Ezawa I: The nutritional evaluation of globin on maintenance of bone metabolism in ovariectomized osteoporotic rats. J Nutr Sci Vitaminol 1994, 40(5):443-457.

21. Guillerminet F, Fabien-Soulé V, Even PC, Tomé D, Benhamou CL, Roux C, Blais A: Hydrolyzed collagen improves bone status and prevents bone loss in ovariectomized C3H/HeN mice. Osteoporos Int 2012, 23(7):1909-1919.

22. Mizoguchi T, Tamura K, Yoshida T, Nagasawa S, Terashima N, Horosawa N, Yagasaki H, Matahira Y, Ito M: Mineral and collagen derived from fish-skin supplementation improves bone metabolism in overiectomized rats part II. J Jpn Dent Mater 2006, 25(2):192.

23. Guillerminet $F$, Beaupied $H$, Fabien-Soulé $V$, Tomé $D$, Benhamou $C L$, Roux $C$, Blais A: Hydrolyzed collagen improves bone metabolism and biomechanical parameters in ovariectomized mice: an in vitro and in vivo study. Bone 2010, 46(3):827-834.

24. NIH Consensus Development Panel: Osteoporosis prevention, diagnosis, and therapy. JAMA 2001, 285(6):785-795.

25. Saito M, Fujii K, Marumo K: Degree of mineralization-related collagen crosslinking in the femoral neck cancellous bone in cases of hip fracture and controls. Calcif Tissue Int 2006, 79(3):160-168.

26. Mizoguchi T, Tamura K, Yoshida T, Nagasawa S, Terashima N, Horosawa N, Yagasaki H, Matahira Y, Ito M: Mineral and collagen derived from fish-skin supplementation improves bone metabolism in overiectomized rats. J Jpn Dent Mater 2005, 24(5):398.

27. Huang TH, Hsieh SS, Liu SH, Chang FL, Lin SC, Yang RS: Swimming training increases the post-yield energy of bone in young male rats. Calcif Tissue Int 2010, 86(2):142-153.

doi:10.1186/1550-2783-10-35

Cite this article as: Takeda et al:: Hydrolyzed collagen intake increases bone mass of growing rats trained with running exercise. Journal of the International Society of Sports Nutrition 2013 10:35.

\section{Submit your next manuscript to BioMed Central and take full advantage of:}

- Convenient online submission

- Thorough peer review

- No space constraints or color figure charges

- Immediate publication on acceptance

- Inclusion in PubMed, CAS, Scopus and Google Scholar

- Research which is freely available for redistribution

Submit your manuscript at www.biomedcentral.com/submit
Biomed Central 